\title{
Two stelae from the Egyptian Museum CG: 22018, 22050
}

\author{
Mohamed Rihan \\ Egypt Ministry of Tourism and Antiquities, Egypt \\ xrehanx@gmail.com
}

Gre za objavo dveh stel vrhunske kakovosti, GG 220I8 in GG 22050, iz egipčanskega muzeja v Kairu, ki sta bili najdeni v družinski grobnici nekropole El-Hassaia blizu Edfuja. Grob, izklesan iz peščenjaka, z napisi in upodobitvami princa Edfuja prispeva pomemben spomenik $\mathrm{k}$ mnogim dosedanjim informacijam o ideoloških in organizacijskih strukturah družbe, znanih iz izredno pomembnega obdobja šestindvajsete dinastije. Eden prinčevih nazivov je bil poveljnik čet v Edfuju. Ti dve steli, ena podarjena s strani njegovega sina in druga s strani njegove matere, opisujeta in razlagata dve generaciji njegove družine z nadaljnjimi člani gospodinjstva, ki so bili eni izmed najpomembnejših uradnikov egiptovskega kraljevega dvora poznega obdobja.

Ključne besede: stele, nekropola El-Hassaia, pozno obdobje, vojaški nazivi, egipčanski muzej v Kairu

This is the publication of two high quality stelae, GG 22018 and GG 22050, from the Egyptian museum in Cairo, which were found in a family tomb at the El-Hassaia necropolis near Edfu. The tomb cut out from sandstone with inscriptions and depictions of the prince of Edfu adds an important monument to the vast number of acquired information about ideological and organizational structures of the society, known from the very important timespam of the twenty-sixths Dynasty. One of his titles was the Commander of troops in Edfu. This two stelae, one offered by his son and the other one of his mother, describe and explain two generations of his family, with further household members were the most important officials in the Late Period at the Egyptian royal court.

Key words: Stelae, El-Hassaia necropolis, Late Period, Military Titles, Egyptian Museum in Cairo

\section{Description}

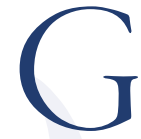
G 22018 is a round top stela with carved decoration and inscription, delimited by an incised border line. The stela made of sandstone, measuring $729 \times 406$ $\mathrm{mm}$, has a lunette $(\mathrm{A})$, below the lunette, there are two registers of roughly equal size; (B) the main field shows the standing owner of the stela on the right, on the opposite side are depicted six gods' figures, (C) consists of Io horizontal lines of text.

\section{Lunette (A)}

The lunette is decorated with a winged sun-disk from which descend on each side an uraeus. To the left and right sides of the winged sun-disk there are respectively two jackals recumbent on the sky-sign separates in a straight line and symmetrically arranged, both with a uraeus on their forehead.

\section{Main inscription (B)}

In this register, which is higher than the following one, an incised human figure, which exhibits greater detail. On the right side is depicted a 
standing woman (Ht-ḩr-ii-ti) (Kamal 19041905, 19-20, II, Pl. VII) in walking pose and facing left. Her very thin right arm is raised forward, with straightened hand and thumb upward, in the gesture of recitation. Her left arm hangs straight down holding a piece of cloth. She wears a tripartite wig, which leaves her ear uncovered, and no details of her dress are indicated. In front of $H t-h r-i \hat{i}-t i$ is a table of offerings with four elongated loaves depicted upright. On the top of the table is the representation of meat, a flower bouquet and a tray with four sealed jars of unguent (two cylindrical $m r h t$-type on the sides, two convex at the center).

Opposite to $H t-h r-i \hat{i}-t i$ and in front of the offering table stand, there are a six figure of gods, the first god is Osiris ${ }^{\mathrm{I}}$, the great god, lord of the Abydos city and Foremost of the Westerners, standing and facing right as a mummified king with green skin, wearing the $h \underline{d} t$ (the white crown) flanked with two long feathers. His both hands are clenched against his chest, clutching the heqa-scepter and the nekhakha-flail ${ }^{2}$. After Osiris there are five gods, all facing right in walking posture. Their left arms are raised forward, with straightened hand and thumb upward, their right arms hanging straight down and holding the anx Ankh symbol of life. The gods from right to left are Isis, Horus, Nephthys, Thot and Anubis.

The hieroglyphic text begins directly below this scene without any separating line. The texts composed of ıo horizontal lines in sunken relief running from right to left.

(I) An offering that the king gives and Osiris, Foremost of the westerners, the great god, The lord to the ennead lord of Shn-rhyt (El-Hassaia necropolis), (2) to the westerners, and to the east-

\footnotetext{
I Osiris was the judge of the dead and the underworld agency that granted all life see Redford 2003, 302-307, Berkley 2003., and the "Lord of Silence" see Wilson 195 I, 302. The Kings of Egypt were associated with Osiris in death - as Osiris rose from the dead so they would be in union with him, and inherit eternal life. Through the hope of new life after death, Osiris was widely worshipped until the decline of ancient Egyptian religion during the rise of Christianity in the Roman Empire see Bury 1958,371.

2 He is identified as Osiris-Khentyamentiu, the great god, Lord of Eternity.
}

erners who are in the necropolis, may you lift up the woman to the creator of her body, (3) may those who carry their masters and those who carry their mistresses hide her mummy in the west, (4) may those four mourners for Re lift up the $\mathrm{Ba}$ of the Known one to heaven, (5) may the four bearers of offerings, the inert gods and praised gods who are upon her throne heal her body, (6) O Gods of the caverns, gods of the great shrine, the crossing-gods, protection- gods and gods of the hall of the two justices, (7) may you give a beautiful burial on the necropolis of the west of Edfu to the beautiful famous and beneficial lady and may you cause to be live the generations (8) of the wife of the commander of army, the great prince in Upper Egypt, and may make the children useful to her, (and) her equal does not exist, (9) Hathor-iy-ti daughter of the overseer of balance Iours vindicated, she who was born of the Lady of the house Ima vindicated, (Io) her house will remain, her offering will be in its place and her children will turn back in front her upon the earth forever.

\section{Textual note}

I: hnt-imntty ntr-c ${ }^{c} 3 n b-t 3-w r-p s \underline{d} . t n b . w-$ Shn-rhyt. The Foremost of the westerners, the great god (Erman and Grapow 1926-1961, III, 468.1 4 - 469.18, ONB 535, Anm. 345), and the lord of the Ennead (a group of nine deities) the lords of $S h n-r h y t \mathrm{Edfu}^{3}$. The combination of epithets for Osiris is uncommon. However, (Yoyotte $1969,134$.$) , it seems, that in this time he was$ the only attested lord of the cemeteries of Edfu.

2: 'Imntyw and 'T3btyw. This two epithets are for Osiris too, 'Imntyw refers to the dead buried in the necropolis on the west bank of the Nile ${ }^{4}$, while 'I3btyw "the Easterners" refer-

\footnotetext{
It is one of many different names of the necropolis of Edfou in the Late Period until the Greco-Roman Period in Egypt, now it's Nag el-Hassia about 2 km north-west of Gabel es-Sirag جارسل لبج, this name appeared in the Middle Kingdom and continued to the Greco-Roman Period; it means "Hathor is coming" Ranke 1935 , 235. The necropolis remained in use until the Greco-Roman Period. The word rxyt may refer to public use of the necropolis as this the word is used as a general term for the Egyptian people.

4 For more of this formal see Sethe 1908-1922, Pyr. 1588c, 1593b, 1598a, I603b. Goyon 1972,277; Leitz2002a,I,360; Moret 1902, I44-45; Leitz2002a,I, 3606I; and Sethe 1908-1922, Pyr. 1588c, 1593b, 1598a, 1603b. Wilson 1997, 77.
} 


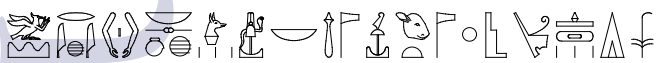

(2)

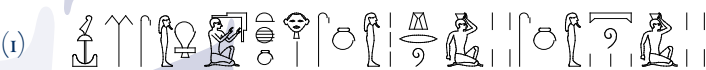

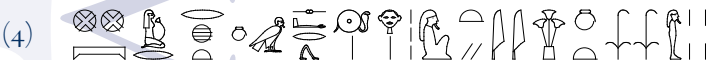

(5) $\Rightarrow$ o $\Rightarrow$

(6)

(6)

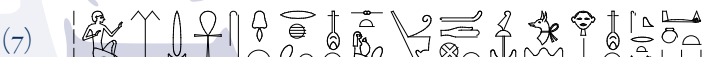

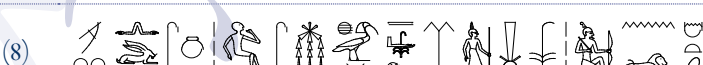

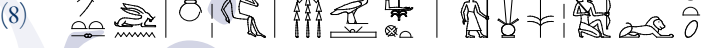

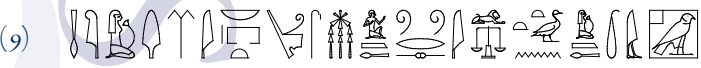

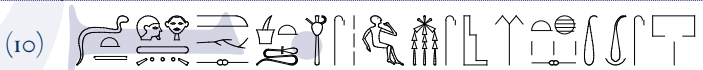

ring to the living on the east bank of the Nile. (Hornung 1971, 118-19; Leitz 2002a, I, I05.) In the Old Kingdom, the IAbtyw are mentioned in the ht $p-d i-n s w$ formulae, they, together with the 'Imnty $w$ help the decease to ascend to his creator and adore the solar god while he is in his bark (Goyon 1972a, 277).

(c) - iw wdn n.sn c tp-t3. an offering for them of vase upon earth. These gods are those of the $8^{\text {th }}$ cavern (Budge $1898,422 \mathrm{ff}$.) from the chapter 168 of the Book of the dead'. This chapter is called the "Chapter of the offerings" (Goyon $1972 \mathrm{a}, 72,120 \mathrm{Nr} .320$.). It is a part of the book called "The gods of caverns in the mysterious Netherworld" and starts with "Rise up of Osiris, soul of Re, that gave back your form, and Rise up, those in the sanctuary, Re will lead you toward your boat. And Rise up Osiris, whose heart beats no more, and who praises Re and Rise up

This 'Chapter of Offerings' has been numbered Chapter 168, but forms a separate composition not found on 'Going out by day' manuscripts: it presents a litany of offerings to deities of particular caverns, and the composition is found on a papyrus from the tomb of king Amenhotep II, perhaps contemporary with his reign see Goyon 1972, [Brooklyn Museum Papyrus 47.218.50] 120, Nr. 320, as well as on other manuscript sources and inscriptions from the Ramesside Period to the Ptolemaic Period see Budge 1898, $422 \mathrm{ff}$., see also Piankoff 1974, Pl. 19; Faulkner 1958, 22. htp-dỉ-nswn Wsirhnt-imntt ntr- ${ }^{c} 3 n b-T 3-w r p s-$ dt $n b-S h n-r h y t$

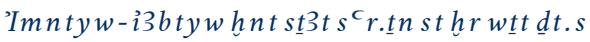

F3w-ḥryw.snf3w-h̆ryw.sn ḥrthn s ${ }^{\complement}$ h.s m imntt

fdwtnnnt ḩ3ywtḥr $R^{c}{ }^{c} r b 3 n r h t r n n t$

fdw-hryyw-3wt nnyw hfyw hrr bhd.s swd $\underline{\text { hlt.s }}$

$n \underline{t} r w-k \operatorname{rty} w$ ntrw-c $3 y t$ ntrw-mhnt $n \underline{t} r w-g s-d p t$ $n \underline{t} r w-w s h t \quad m 3^{c} t y$

di.tn kerst nfrt hrr sțt imntt Bhdt $n$ st $n f r t$ rht $m n h t s^{c} n h \underline{d} 3 m w$

hmt $n$ imy-r $m \check{s}^{c} s n-n s w$ wr $m$ T3-šm $m^{c} 3 h m s w$ n.s $n$ wn mitt.s

$H t-h r-i i . t i \quad m 3^{c}-h r w$ s $3 t n$ imy-r mh3t'Iwwrs $m 3^{c}-h r w m s(t) n n b t-p r \operatorname{Im} 3 m 3^{c}-h r w$

pr.s mn.ti ht.s mst.s msw.swdbm-ht.shrtpt3 $d t$

Amon, whose body is hidden, (the eldest son of $\mathrm{Re})$. And Rise up Osiris! Re offers you his hands and Ptah protects you. And Rise up Osiris, your two sisters Isis and Nephtys prostrate themselves before you. Rise up, the one whose mysteries are hidden; who illuminates the Douat with the light of his eyes. Rise up Orion, master of life! Your son Horus gives you his scepter Djam. Rise up child Khepri, the offspring of Nout and Re. Rise up Thou rich in adornments! Temples contain your hidden picture. Rise up eldest of elders, the great, victorious Osiris! Maat is with you; Isis is your protection. Rise up, god of many forms! The earth has your image and your mummy, and the sky is filled with your divine soulstar. Rise up, O Eternal One who surrounds the earth ... All beings are cradled in your arms." (Goyon 1972, 120, Nr. 320; Petosiris II, 175). For the Chapter 168 see: Barguet 1976, 242-46; Budge 1898, 422 ff.; Naville i886, Pl. CLXXXVII-CLXXIX.

On papyri such as the Brooklyn Museum Papyrus 47.218.50, these gods are also called "the gods of the $8^{\text {th }}$ cavern, savior(s) sound of judgment, distinguishing truth from falsehood" (Allen 1974,162 .), and most of those gods of the $8^{\text {th }}$ 
cavern consist of groups of four deities (Goyon, 1972, Pl. XIIIA.).

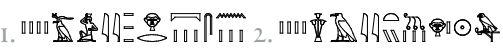

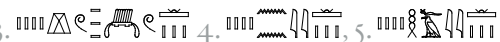

A short notice about every group of those gods:

(I) masters" consist of four persons, each bearing another person on his shoulder ${ }^{6}$. They are sometimes represented as one person carrying a child on his shoulder and with the number four written beside him (Allen 1974, I62, Nr. 172, a, S I.). The role of these gods is described in the Book of the dead "the bearers of their masters to the sky at the prow of the bark of Re" (Budge 1898,423 .), so the deceased wishes that they bear him to the sky to accompany the god Re at his rising and his setting "may they let Osiris (= the Dead) see Re at his rising" (Allen 1974, I62, I68, S I.).

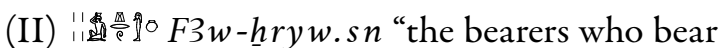
those who are under them" they are represented at the Osireion of Abydos as a group of four persons, everyone bearing on his shoulder a woman, the text describe them

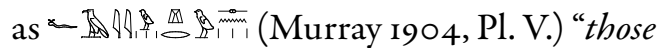
who bear their mistresses" (literally the bearers of those who are under them). The job of the $F 3 w-h r y w . s n$ and $F 3 w-h r y w . s n$ are to hide the body of the deceased in the necropolis (Leitz 2002b, III, 190.) as stated in the present text $t h n s^{c} h$. $s$. In the Book of the dead they play the same role as the $F 3 w$ hryw.sn (Allen 1974, 168.).

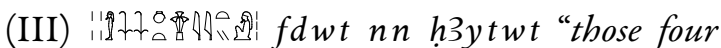
mourners" the Greco-Roman word h3yty refers to Isis and Nephthys, who mourn for their brother Osiris (Wilson 1997, 611.). The word is usually determined by the two sisters as mourners (Goyon 1972a, 75; Barguet 1976, 243.). Sometimes four goddesses are

6 The same group also appeared on the sarcophagi of the Late Period

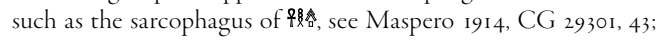
Murray 1904, 3 . shown instead of two; the four goddesses are Isis, Nephthys, Nut and Tefnut (Cauville $1997,292,9-12, \mathrm{Pl}$. I54.). In the chapels of Osiris in the temple of Dendara the number of these goddesses increased to eight (Cauville 1997, 213, 5, Pl. 102.). Those gods represented as a woman (or four women) leaning forward, with hands raised to falling lock of hair (Allen, 162, a 3, 168, a 3.). Their job as mentioned here is to lift up the $\mathrm{Ba}$ (or the body) of the deceased to heaven to accompany the solar god (Leitz $2002 \mathrm{~d}, \mathrm{~V}, 9-\mathrm{IO}$.), as well as "they give bread to Osiris (N)" (Allen 1974, 164.) and they "put Osiris (N) with the followers of Re, the gods, lords of the west".

(IV) offerings" (Murray 1904, 4.) or "the bearers of the offerings" in the Osirion of Abydos this title describes a group of three persons carrying the offerings (Murray 1904, Pl. V.), they are represented as two gods and two goddesses raising their hands holding the bread and beside them was written the number four ${ }^{8}$, it is mentioned that

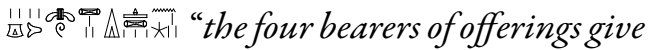
the offerings to the gods" (Cauville 1997, 292, I4.), as well as they let Osiris (= the Dead) be like in the Netherworld.'

(V) 孙量通 Nnyw the fatigued (Hassan 1944, 314.), in the coffin texts (Faulkner 1962, 134.) they are used as epithet for some gods such as Osiris, Ptah and the sun god (Leitz 2002c, IV, 249.). In the coffin texts the word is written in different forms such as

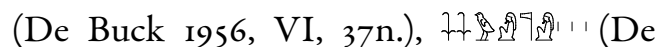

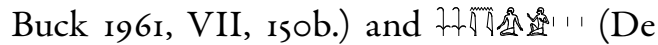
Buck 1956, VI, 26Ie.), the last determinative of the word 1 is that the one survived as the Greco-Roman Period, in addition to that of

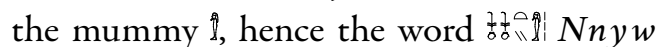

See Goyon 1972,75; Barguet 1976, 243

8 Leitz 2002C, IV, 41; Murray 1904, Pl. V. On the sarcophagus of

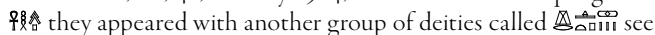
Maspero 1914, 54.

For more see Allen 1974,164 


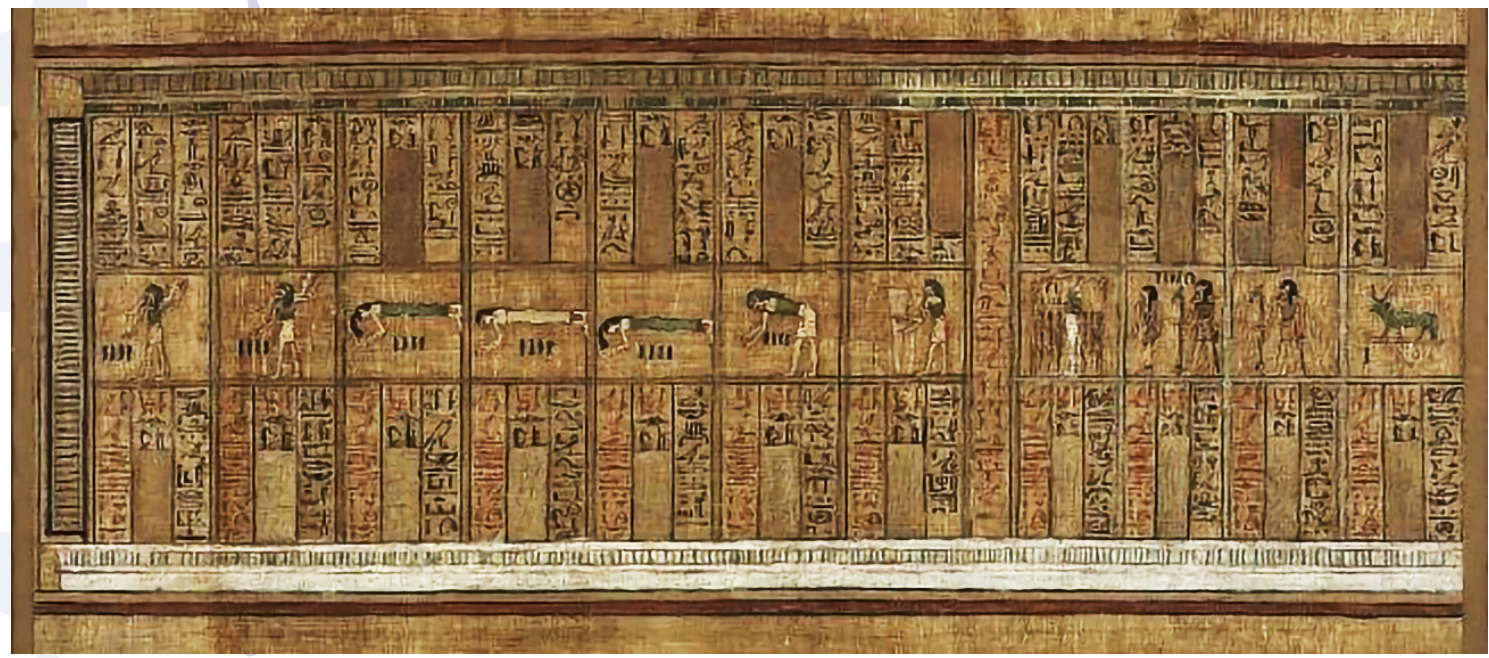

Figure I The Vignette of the Chapter I68 A, B and D of the Book of the dead (Barguet 1967, 242.)

became to give the meaning "the dead ones" (Cauville 1997, 202.), we find also the four Nnyw represented as four ladies, all of them sitting on a bed (Cauville 1997, Pl. 94.). Their role according the Book of the dead "may they put friendliness toward Osiris (N) in the broad hall of the two truths" (Allen 1974, 164.).

(VI) 得刑 $h f 3 w$ "the gods of reverence" the word derives from the verb \& $\mathrm{Hf}(\mathrm{A})$ "to praise, to revere" (Wilson 1997, 641.). They are four deities (Leitz 2002d, V, 130.) ${ }^{10}$ appearing in the $8^{\text {th }}$ cavern at the Chapter 168 of the Book of the dead ${ }^{\mathrm{II}}$.

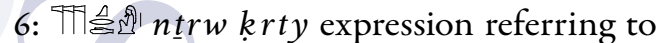
the inhabitants of the different (Maspero I9I4, 43, 54) zones called qrrt (Nagel I929, 43, 21.). Goyon translated the term as "the gods of the caverns" (Goyon I972a, 277.) referring to the $k r$ -

Io See Book of the Dead, Chapter 175 (in pBM EA 10470); cf. e.g. [Faulkner and Goelet 1998, Pl. 29, Cols 16-19]: iw. $k r h h n h h\langle n\rangle$ ${ }^{c} h^{c} w n h h$; [...] iw.i grt $r$ hdd(i) irt n.i nbt; iw t3 pn riy

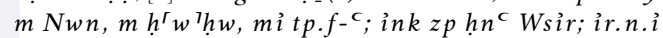

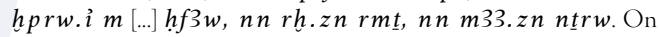
another similar passage from the Coffin Texts, see De Buck 196I, VII, II $30, \$ \$ 46 \mathrm{IC}-47 \mathrm{Ig}$; De Buck 1935-196I, II, 80, \$\$ $27 \mathrm{~d}-43 \mathrm{~h}$. For an analysis, see: Maravelia 2012, 103-1, see also Maspero 1914, 43.

I I In the Book of the dead there is a very characteristic and interesting eschatological passage, where the supreme solar creator, the primeval god Ra-Itum predicts the catastrophic end of the Universe, which will destroy every god and every human on his own, see Barguet 1976,243. see also Budge 1898, 422, 424; Naville 1886, 185 . $r t$-caverns in the chapter $168 \mathrm{~A}-\mathrm{B}$ in the Book of the dead ${ }^{12}$ and the Books of afterlife in New kingdom (Murray 1904, Pl. V.; Leitz 2002, VII, 223-24.). They appear in caverns, which look like the boxes, their job was to accompany ReOsiris who judges the bas (Goyon 1976, 169.), they are the inhabitants of the caverns (qrrt) of the Netherworld $(d w 3 t)$ and protect them, and they guide the deceased through the Netherworld and lead him to the good road in the west (Herbin 1994, I, 21, VIII, 23-24.).

6: $x+80$ trw- $43 y t$ "the gods of the shrine" (Leitz 2002c, IV, 477.) are mentioned among the gods who give the deceased a beautiful burial at the necropolis of Edfu (Kamal 1904-1905, CG 22018 , 19.). The word aAyt refers either to the whole or part of a temple building (Wilson 1997, 135; Daumas 1958, 228, Nr. 5.).

6: “ $n$ trw-mhnt "the gods of crossing", are a group of deities who appeared in the Greco-Roman Period (Leitz 2002c, IV, 494.), they were probably responsible for crossing or passing the deceased through the rivers in the afterworld, so the word sometimes determined with the sign $e^{13}$.

\footnotetext{
I2 See in Barguet 1976, 242-46; Budge 1898, 422 ff.; Naville 1886, Pl. CLXXXVII-CLXXIX; Faulkner, 1985, 162-66.

I3 See in Kamal 1904-1905, CG 22049.
} 
6: 119 $n t r w-g s-d p t$ "the gods of protection" are considered a group of the 77 gods of pharbaitos and the gods who give the deceased a beautiful burial at the necropolis of Edfu (Leitz 2002c, IV, 549.). They are also mentioned as gods of protection who protect their master Horus (Leitz 2002, VII, 32,17.) and Re (Leitz 2002d, V, I97, Iо.).

6: 得盟 $n t r w-w s h t-m 3^{c} t y$ "the gods of the hall of dual justices" (Leitz 2002c, IV, 482; VIII, 23-24.), this expression refers to the 42 judges of the court of Osiris (Goyon 1972a, 247, Nr. 2.). They appeared in the chapter $186 \mathrm{~A}-\mathrm{B}$ of the Book of the dead (Faulkner 1985, 162-66; Cauville 1997, 145.).

7: 很 $d 3 m w$ refers either to a group of young men or children, or to "rising generations" of people (Wilson 1997, I219; Faulkner 1953, 40$4 \mathrm{I})$. In another stela (CG 2202I) from the same province the word means "the generations" (Kamal 1904-1905, CG 22021, 22.).

2- Stela CG 22050 of P3- $\check{S} w$ (Ranke 1935, I, III.) son of P3-mnh (Ranke I935, I, I08.) and the lady of the House $H t-h r-i i$.ti (Daressy I895, II6-II7, CXXXI.) found in the same tomb as the previous stela, it is a round top stela too with carved decoration and inscription, delimited by an incised border line. The stela of sandstone, measuring $789 \times 417 \mathrm{~mm}$, the stela has a lunette (A) Below the lunette, there are two registers of roughly equal size. (B) the main field shows the laying owner of the stela on the in the center of the register. Around him are seven figures of gods. (C) consists of Io horizontal lines of text.

\section{Lunette (A)}

The lunette is decorated as the previous stela with a winged sun-disk from which descend on each a uraeus. To the left and right sides of the winged sun-disk there are respectively the jackals recumbent on the sky-sign separates in a straight line and symmetrically arranged, both with a uraeus on their forehead.

\section{Main inscription (B)}

In this register is higher than the following one, in the center of the register shows $P 3-\overleftarrow{S} w$ the owner of the stela laying as the mummy form of Osiris on a bed which has leonine legs and head, and next to $P 3-\check{S} w$ the god Anubis in walking pose and facing right. He wears a flaring kilt projecting from below the stomach and reaching down to a point just below his knees. And he making the preserve (a body) by embalming the deceased and wrapping it in cloth. His right arm hangs down and his right hand touching the body of the deceased $P 3-\check{S} w$. Anubis's left arm is raised forward, with straightened hand and thumb upward, and holds a vase with oil ${ }^{14}$.

On the left sits of the bed is the goddess Isis in walking pose and facing left. Her left arm is raised forward, with straightened hand and thumb upward, in the gesture of recitation. Her right arm hangs straight down. She wears a tripartite wig, which leaves her ear uncovered, and no details of her dress are indicated. Behind her two sons of Horus are Imsety and Duamutef

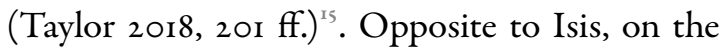

14 Anubis was a protector of graves and cemeteries. Several epithets attached to his name in Egyptian texts and inscriptions referred to that role. Khenty-imentiu, which means "foremost of the westerners" and was also the name of a different canine funerary god, alluded to his protecting function, because the dead were usually buried on the west bank of the Nile (Hart 1986, 23-24.). He took other names in connection with his funerary role, such as $t p y$ $\underline{d} w \cdot f^{\prime \prime} \mathrm{He}$ who is upon his mountain" (i.e. keeping guard over tombs from above) and $n b-t 3-d s r$ "Lord of the sacred land", which designates him as a god of the desert necropolis. (Vischak 2014, 27, 135; Hart 1986, 23-24; Wilkinson 2003, 188-90.). The papyrus Jumilhac recounts another tale where Anubis protected the body of Osiris from Set. Set attempted to attack the body of Osiris by transforming himself into a leopard. Anubis stopped and subdued Set, however, and he branded Set's skin with a hot iron rod. Anubis then flayed $S e t$ and wore his skin as a warning against evil-doers who would desecrate the tombs of the dead. (Armour 2001) Priests who attended to the dead wore leopard skin in order to commemorate Anubis' victory over Set. The legend of Anubis branding the hide of $S e t$ in leopard form was used to explain how the leopard got its spots (Zandee 1960, 255.). Embalmer 3s jmy- wt "He who is in the place of embalming", Anubis was associated with mummification. He was also called $n t y y-n r$ "He who presides over the god's booth", in which "booth" could refer either to the place where embalming was carried out or the pharaoh's burial chamber (Hart 1986, 23-24; Wilkinson 2003,188-90.).

is This two sons of Horus are Imsety, in the form of a human, representing the South, who protected the liver of the deceased, protected by his mother Isis, and Duamutef, in the form of a jackal, 


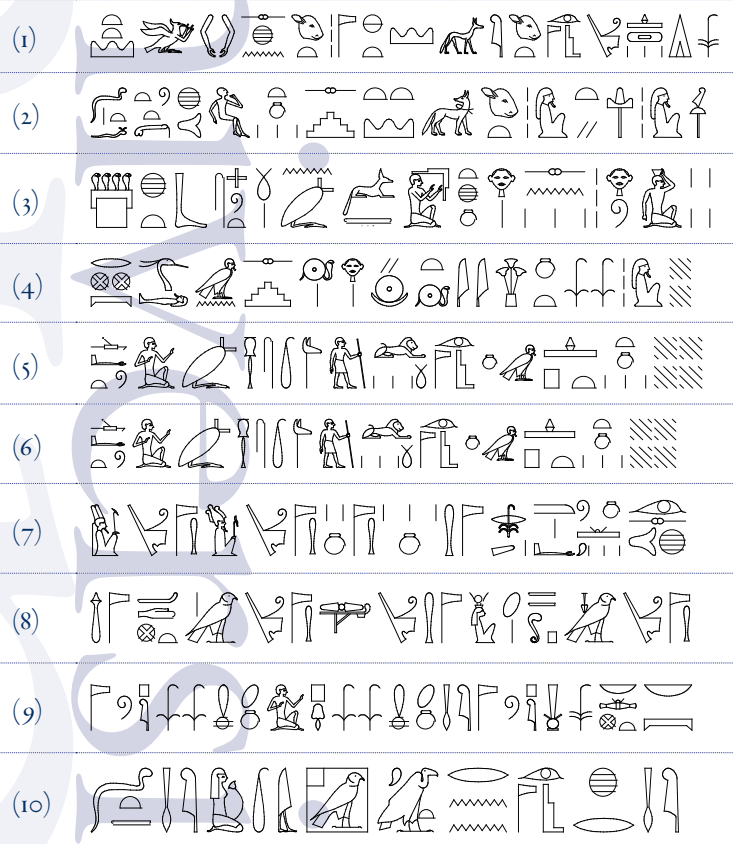

right sits of the bed is the goddess Nephthys in walking pose as Isis but she facing right and behind her two sons of Horus, Hapi and Qebehsenuef (Aufderheider 2003, 237) ${ }^{16}$.

\section{Written register $(\mathrm{C})$}

The hieroglyphic text directly begins below this scene without any separating line. The texts composed of to horizontal lines in sunken relief running from right to left.

(I) An offering that the king gives and Osiris the foremost of the westerners, to the ennead in front of Shn-rhyt (El-Hassaia), (2) to the Westerners and to the Easterners who are in the necropolis, may you lift up the child to the creator of his body, (3) may those who carry their masters hide the secret form of the lord of linen through the portal (of the west), (4) may those mourners upon Re lift up the ba of the beneficent to heaven, (5) may you make satisfying the

representing the East and protected the stomach of the deceased, protected by Neith

I6 This two sons of Horus are Hapi, in the form of a baboon, representing the North, who protected the lungs of the deceased, protected by his mother Nephthys, and Qebehsenuef, in the form of a hawk, who was representing the West and protected the intestines of the deceased, protected by Serket.

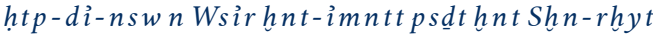

'Imntyw i3btyw hnnt st $3 t s^{C} r . \underline{t} n \underline{h} r d \underline{h} r w \underline{t} t \underline{d} t . f$

f3w-ḥryw.sn ḥrthnn š̌t $n n$ nb-š̌r imì-tw sbht

(imntt)

fdwnnntḩ3ywt hrr $R^{c} s^{c} r b 3 n 3 h r n n t$

[ir].tnh htp b3 nWsirimy-rmšc wrwsr.tismr $w^{c} t y$

imy-rssmwt ḳn mskytidnw tpy nḥm.f

irshrw.fm- ${ }^{C} r s y h m-n t r h m t-n w h m-n t r s n-n w$

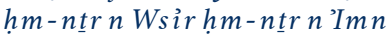

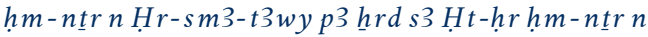

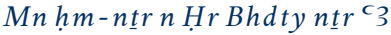

$n b$ pt nb Msn sn-nsw P3-Š $w m 3^{c}-h r w s 3 n m i-n n$ $P 3-m n h s 3 n m i-n n P 3-\check{S} w$

$m 3^{c}-h r w h r W s i r r n n m w t . f H t-h r-i \imath . t i m 3^{c}-h r w$ $\underline{d} t$

ba of Osiris, the great commander of the army (= the general), the strong one, the unique courtier, (6) the overseer of the horses (cavalry), the strong in the battle, the first deputy of his majesty (7) who made his plans in the south, the priest of the third Philae, the priest of the second Philae, and the priest of Osiris, the priest of Amon, (8) the priest of Harsomtous son of Hathor, the priest of Min, the priest of Horus of Behdet, the great god, (9) lord of the sky, lord of Edfu, the royal brother Pa-shu the justified, son of the same-titled Pa-menkh son of the same-titled Pa-shu (Io) the justified before Osiris, his mother name is Hathor-iy-ti the justified forever.

\section{Textual notes}

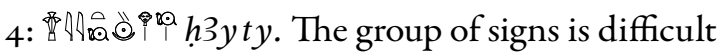

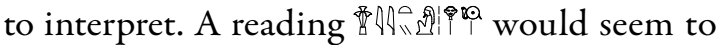
be the only possibility, It is quite extraordinary that as many as three reporters should be attested on one stela. As $P 3-\check{S} w$ worked for the palace guard, he must have had regular contact with people reporting matters from 
the inner court circles to the outside world ("rod). For the title 'reporter"

5: 1 imy-r ssmwt "overseer of the horses" or "the commander of the cavalry", appeared in dynasty 18 as Grapow 1926-1961, IV, 276, 18-20, Hannig 2006,825 .), the person bearing this title was responsible of the administration of the chariotary and accountable directly to the king (Al-Ayedi 2006, II4-I5.), it is a civil job more than a military job, the king was given it as an honorary title to the high retired officers (Helck 1939, 5962.).

6: \을 idnw "deputy" (De Meulenaere 1993, $135-36,47$.) this word was used firstly as a verb te ${ }^{\infty}$ idn "serve instead of, replace" from the Middle kingdom onwards (Erman and Grapow 1926-1961, I, 154, I-5; Faulkner 1953, 35.), idnw is equal the Wakel لكيكال in Arabic (Wild 1954, I82.), meaning literally "representative", but it appeared in the title $i d n w n p 3 m \check{s}^{c}$ "lieutenant-commander of the army" who commands under $i m y-r m \check{s}^{c}$, the persons who bear the title idnw of the army were very high-ranking officers. The idnw "deputy" was an administrator rather than an active soldier, yet higher in the military hierarchy was the lieutenant-commander, such as in our stela where the word idnw also indicates the deputy of the civil officials (Faulkner 1953, 46; Spiegelberg 1913, 36, lines 9, 14.) when the specific function is clear.

$9: \neq \downarrow s n-n s \mathrm{w}$ "the brother of the king", a honored title bore it the members of the family of $P 3-\check{S} w$ at Edfu in the second century B.C. (Yoyotte 1969, 135.). This title often accompanies, in hieroglyphic texts, the military title of $i m y-r$ $m \check{s}^{c}(w r)$ "the great commander of the army",

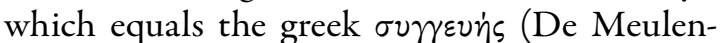
aere $1959,2$.$) since the 30^{\text {th }}$ dynasty (De Meulenaere 1959, 22, Nr. 2; Petrie 1909, I3, Pl. 31-32.). The same title did not appear in Greek and Demotic papyri before I20 B.C.

17 It seems that the scribe wrote the name, and he confused between the word HAyty "two lights (= the sun and moon)" and the word HAyty "the two mourners".

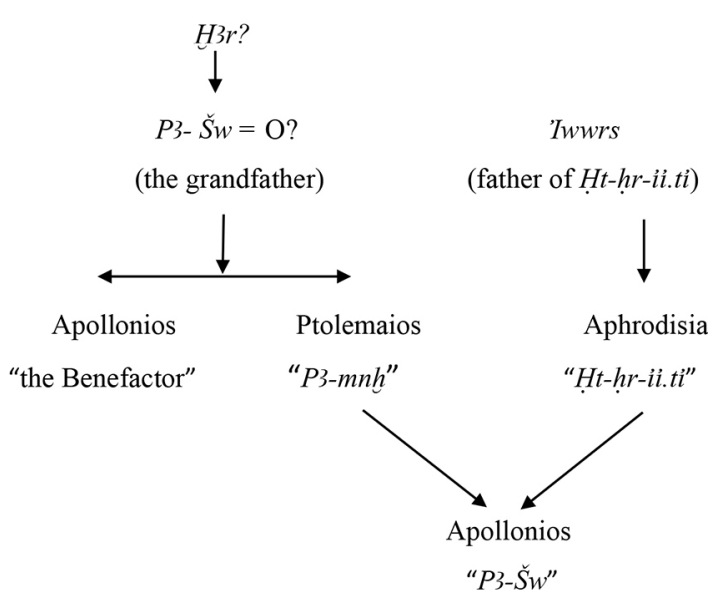

\section{Genealogy}

It is difficult to reconstruct all the connections between members of $P 3-\check{S} w$ 's family with certainty. Several people are mentioned in both stelae from his earlier life. Also the strategic location of Edfu for controlling the trade in elephants and the gold and mineral mining regions in the eastern desert prompted the Ptolemies to make the town an important garrison site (Manning 1997,8 .), the family of $P 3-\check{S} w$ is the grandfather $\mathrm{Pa}-\mathrm{Shu}$ and father $\mathrm{Pa}-$ Menkh, who was married Hathor-ieie-ti daughter of Iours and begat his son Pa-Shu (Munro 1973, 253.).

$P 3-\check{S} w$ was a member of a family army men in the Province of Edfu in the $2^{\text {nd }}$ and $\mathrm{I}^{\text {st }}$ centuries B.C., every member of his family carried the title $i m y-r m \check{s}^{c} w r$ the great commander of the $\operatorname{army}(=$ the general), the same title mentioned in demotic texts as $p 3 s r t k s$, it is probably that this title refers to the "local strategos" of the nome or as H. de Meulenaere called it "Stratéges indigénes" (De Meulenaere 1959, 2, 5, 7.), but Yoyotte suggests that $i m y-r m \check{s}^{c} w r$ title in the $2^{\text {nd }}$ $-\mathrm{I}^{\text {st }}$ century B.C was a military rank for the officers (Yoyotte 1969, 135.). ${ }^{18}$.

I8 There is another stela from the same province, which bears the name of another $P 3-(n)-\check{S} w$ son of $H 3 r$ who carries the same title $i m y-r m \check{s} c$ and $i m y-r h r p k n w$ "the commander of the military and the commander of cavalry". It was probably the grandfather? of the owner, see Kamal 1904-1905, CG 22021, 19-20, II, Pl. VIII; Yoyotte 1969, 135 $\sqrt{ }$

(

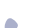


In addition of the civil titles $P 3-S ̌ w$ had religious titles, he was (like his father and grandfather) a priest for more than one great god such as Osiris, Amon, Horsamotus, Min and Horus of Behdet, this shows his high status in priesthood. If we found a connection between the title imy-r $\mathrm{mSa}$ wr and the titles of the priesthood, we could suggest that the family of $P 3-\check{S} w$ probably supervised all the southern Nomi of the previous gods such as Dendara (Nome of Osiris and Horusamotus), Coptos (Nome of Min), Thebes (Nome of Amon) and Edfu (Nome of Horus of Behdet).

\section{Povzetek}

Članek je objava dveh visokokakovostnih stel, GG 22018 in GG 22050, iz egipčanskega muzeja v Kairu, ki pripadata princu iz Edfuja, znanem do grško-rimskega obdobja. Vsaka od njegovih zgoraj omenjenih funkcij je bila rekonstruirana iz besedil in upodobitev na stelah. Zanimiv je tudi kontekst, v katerem so mu stele postavili in v čigavem imenu so jih uporabljali. Dejansko so bile stele resnično vsestranske monumentalne oblike, ki so jih uporabljali v celotni faraonski dobi vse do koptskega obdobja.

Marca leta 1884 je G. Maspero med vasema El-Qasaa in Er-rimtah izkopal pozno egipčansko nekropolo El-Hassaia, ki ponuja nekaj pomembnih informacij o egiptovskih ekspedicijskih dejavnostih v Zgornjem Egiptu ob koncu zadnjih egiptovskih dinastij.

Zgoraj opisani steli sta del skupine medsebojno povezanih grobnih stel iz nekropole El-Hassaia, ki sta bili napisane $v$ dveh različnih jezikih (v egipčanskem in v starogrškem jeziku) in so za vsakega omenjenega posameznika uporabljali tudi dve različni imeni. Njuni različni vizualni slogi in pogrebna besedila prav tako zagotavljajo dokazano dvojno identiteto med grško-egiptovskimi posamezniki ptolemajske vlade.

G. Maspero je v enem izmed grobov našel mumijo s poslikano kartonažo, prekrito s prizori in hieroglifi, ohranjeno besedilo pa nakazuje, da mumija pripada eni od prinčevih hčera, Maspero predlaga »c'était donc le tombeau de la famille du prince d' Edfou Penshou, et le cartonnage avait appartenu à la momie de la fille de ce personnage $\ll$. V drugi grobni dvorani iste grobnice je našel ostanke kartonaže z zapisoma dveh nazivov, iz katerih je jasno razvidno, da kartonaža pripada » povelj- niku vojske in nadzorniku konj $\mathrm{Pa}($ en $)$ shou-ju «. Slednji nosi enake nazive kot naš Pashou, zato je bil verjetno član iste družine kot lastnik stele št. 22050. Po Masperovih besedah je nekropola v uporabi od konca ptolemajskega obdobja do začetka rimskih časov.

H. de Meulenaere opaža, da je to ime egipčanska inačica grškega imena Psais, ki je bil skupaj z družino razvrščen za stratega Apollinopolisa. Sklicevanje na isto osebo z dvema imenoma je dobro znano. Yoyotte potrjuje stališče H. de Meulenaereja v svoji izjavi, da so bila vsa imena, navedena na obeh stelah egipčanske inačice kot grška imena, potrjena na štirih pogrebnih stelah, treh iz kairskega muzeja in četrte iz Grško-rimskega muzeja v Aleksandriji. Po drugi strani so nekatere grške osebe raje pisale svoja imena na svojih kipih v hieroglifih, kot vidimo na primeru kipa Georgesa, sina Ptolemaja, stratega Dendare iz ptolemajskega obdobja.

\section{Summary}

This paper is the publication of two high quality stelae, GG 22018 and GG 22050, from the Egyptian museum in Cairo, which both belong to the well known as the prince of Edfu up to the Greco-Roman period. Each of his above mentioned functions was reconstructed from the texts and images of the stelae. Interesting is also the context in which the stelae were erected and on behalf of whom they were used. Indeed, the stelae were a truly versatile monumental form, employed over the whole pharaonic era throughout to the Coptic period.

In March 1884 G. Maspero excavated between the village of El-Qasaa and Er-rimtah the late Egyptian $\mathrm{Ne}$ cropolis El-Hassaia, which provides some important information on Egyptian expeditionary activity in Upper Egypt at the end of last Egyptian dynasties.

The two stelae analysed above are part of a group of interconnected grave stelae from the necropolis of El-Hassaia, which were written in two different languages (in the Egyptian and the Old Greek language) and were also using two different names for each mentioned individual. Their different visual styles and funeral speeches also provide proven evidence of double identity among Greek-Egyptian individuals of the Ptolemaic government.

In one of the tombs G. Maspero found a mummy with a painted cartonnage covered with scenes and hieroglyphs, the remaining text indicates that the mummy 

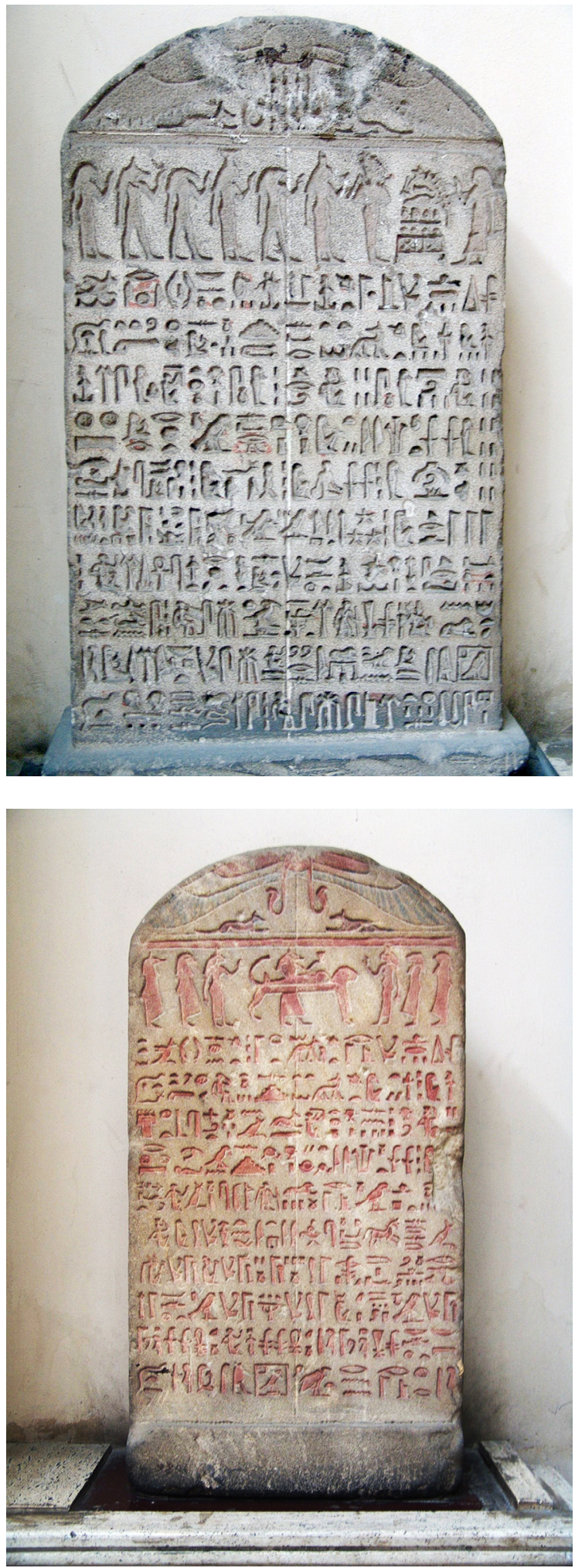


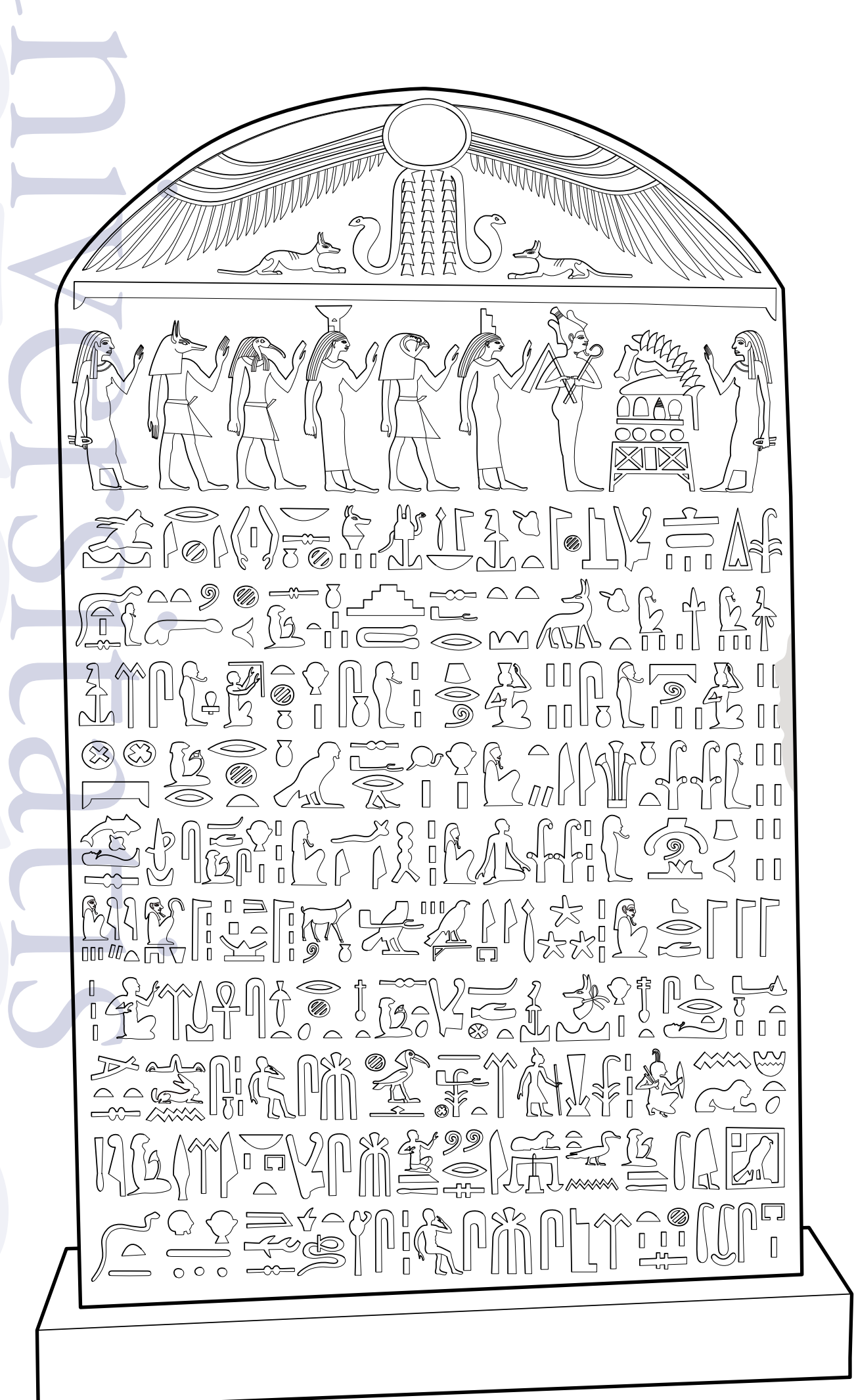




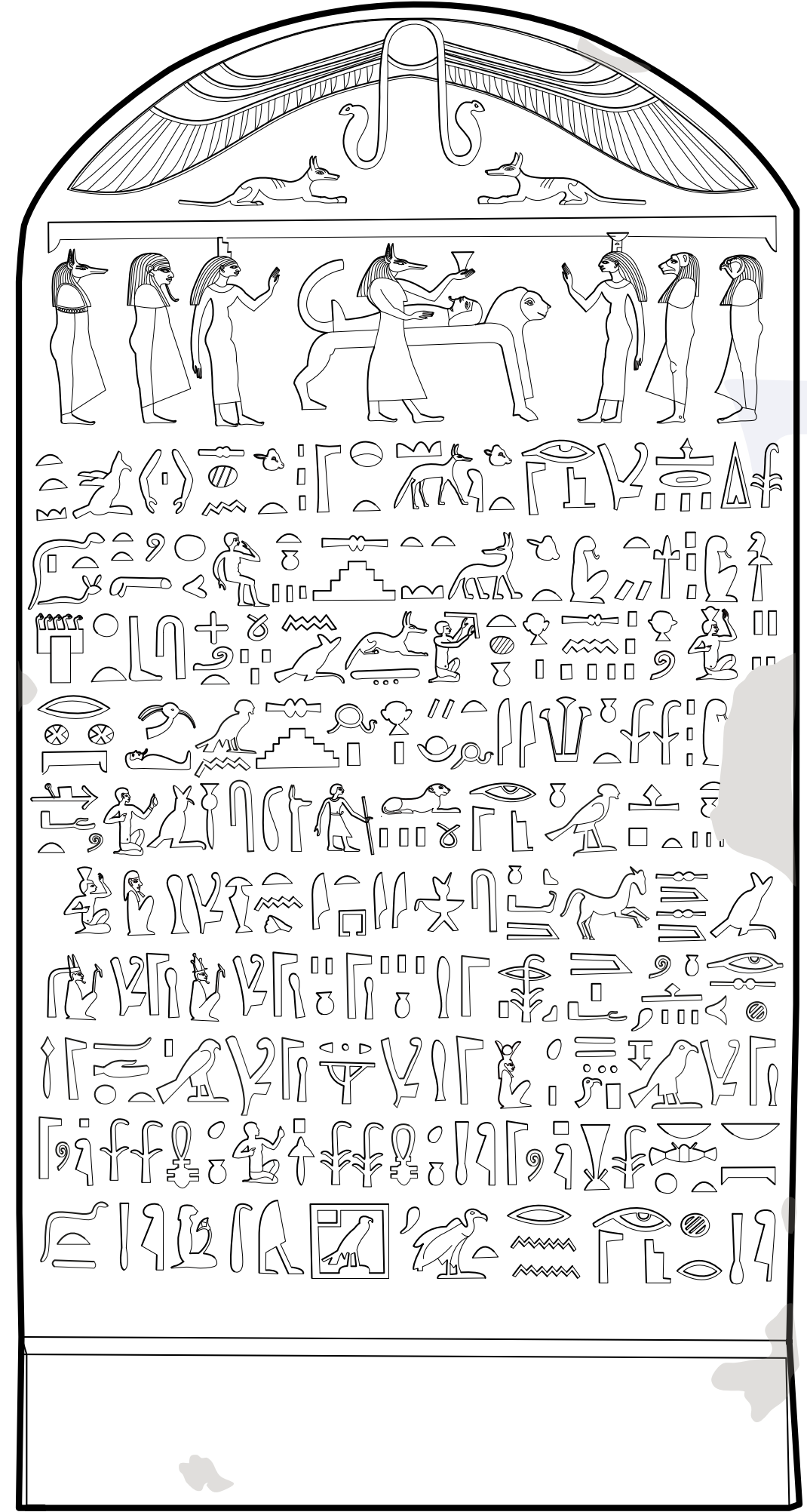


belongs to one of the daughters of the prince, Maspero suggests "cétait donc le tombeau de la famille du prince d'Edfou Penshou, et le cartonnage avait appartenu à la momie de la fille de ce personnage". In another chamber of the same tomb he found remains of cartonnage, which has two written titles, clearly showing that the cartonnage belongs to "the commander of the army and the overseer of the horses $\mathrm{Pa}(\mathrm{en})$ shou". He bears the same titles as our Pashou, so he was probably a member of the same family as the owner of the stela Nr. 22050. According to Maspero the necropolis dates from the end of the Ptolemaic era to the beginning of the Roman times.

H. de Meulenaere sees that this name is the Egyptian alteration for the Greek name Psais who is, together with his family, classified as the strategos of Apollinopolis. The reference to one and the same person by two names is well known. Yoyotte confirms the position of H. de Meulenaere in his statement that all the names on the two stelae were Egyptian names for Greek names affirmed on four funerary stelae, three from the Cairo Museum and the fourth from the Greco-Roman Museum in Alexandria. On the other hand, some Greek persons seemed to prefer writing their names on their statues in hieroglyphs as we see in the example of the statue of Georges, son of Ptolemys, the strategos of Dendara in the Ptolemaic period.

\section{References}

Allen, T. G. 1974. The Book of the Dead or Going Forth by Day': Ideas of the Ancient Egyptians Concerning the Hereafter as Expressed in Their Own Terms. Studies in Ancient Oriental Civilization 37. Edited by E. B. Hauser. Chicago: The University of Chicago Press.

Al-Ayedi, A. 2006. Index of Egyptian Administrative, Religious and Military Titles of the New Kingdom. Ismailia, Egypt: Obelisk Publications.

Armour, R. A. 2001 . Gods and Myths of Ancient Egypt. Cairo; New York: American University in Cairo Press.

Aufderheide, A. C. 2003. The Scientific Study of Mummies. Cambridge: Cambridge University Press.
Barguet, P. 1976. Le livre des Morts des anciens Égyptiens, Littératures Ancienne ProcheOrient (Book I). Paris: Éditions du Cerf. Budge, E. A. W. 1898. The Book of the Dead: The Chapters of Coming Forth by Day; The Egyptian Text According to the Theban Recension in Hieroglyphic. Edited from Numerous Papyri, with a Translation, Vocabulary, etc. Vol. I-3. London: Kegan Paul, Trench, Trübner.

Bury J. B. 1958. History of the Later Roman Empire from the Death of Theodosius I. to the Death of Justinian. Mineola, NY: Courier Dover Publications.

Chassinat, É. 2009. Le temple d'Edfou III,

Mémoires publiés par les membres de la Mission Archéologique Française au Caire 2o. Le Caire: Institut Français d'Archéologie Orientale.

Cauville, S. 1997. Le temple de Dendara X, Les chapelles osiriennes. Cairo: Institut français d'archéologie orientale.

Daressy, G. I895. "Notes et Remarques." In Recueil de travaux relatifs à la philologie et à l'archéologie égyptiennes et assyriennes 17 , II3-2O.

Daressy, G. 1916. "Statue de Georges prince de Tentyris." Annales du Service des Antiquités de l'Égypte 16: 268-70.

Daumas, F. 1958. "Les Mammisis des temples égyptiens." In Annales de l'Université de Lyon, troisième série, Lettres 32. Paris: Les Belles Lettres.

De Buck, A. 1935-196r. The Egyptian Coffin Texts. 7 Bde, Chicago: The University of Chicago Press.

De Meulenaere, H. 1959. "Les Stratéges indigénes du Nome Tentyrite à la fin de l'époque ptolémaïque et au début de l'occupation romaine." Rivista Degli Studi Orientali 34: I-25.

De Meulenaere, H. 1969. "Les steles de Nag elHassaia." Mitteilungen des Archäologisches Institut, Abteilung Kairo 25: 90-97. 
De Meulenaere, H. 1993. "Trois membres d'une famille sacerdotale thébaine." Chronique d'Égypte 68: 45-64.

Erman, A., and H. Grapow. 1926-1961. Wörterbuch der Aegyptischen Sprache. Berlin: Akademie-Verlag.

Faulkner, R. O. 1953. "Egyptian Military Organization." Journal of Egyptian Archaeology 39: 32-47.

Faulkner, R. O. 1958. An Ancient Egyptian Book of Horus. Pap. Brit. Mus. 10569. Oxford: The Griffith Institute at the University Press.

Faulkner, R. O. 1962. A Concise Dictionary of Middle Egyptian. Oxford: Griffith Institute.

Faulkner, R. O., and C. Andrews. 1985. The Ancient Egyptian Book of the Dead. London: Publ. for the Trustees of the British Museum by British Museum Publications.

Faulkner, R. O., and O. Goelet. 1998. The Egyptian Book of the Dead: The Book of Going Forth by Day. San Francisco: Chronicle Books.

Gardiner, A. 1947. Ancient Egyptian Onomastica I. Oxford: Oxford University Press.

Goyon, J.-C. 1972. Confirmation du pouvoir royal au Nouvel an, Brooklyn Museum Papyrus 47.218.50, Bibliothèque d'étude 52. Le Caire: Institut français d'Archéologie orientale et Brooklyn Museum.

Goyon, J.-C. 1972a. "Rituels funéraires de l'ancienne Egypte. Le Rituel de l'Embaumement. Le Rituel de l'Ouverture de la Bouche." In Les Livres des Respirations, Littératures anciennes $d u$ Proche-Orient, 4. Paris: Les Editions du Cerf.

Goyon, J.-C., and C. R. de A. Piankoff. 1976. The Wandering of the Soul, Bollinger Series XL, 1974, Bibliotheca orientalis 33. Princeton, NJ.
Hannig, R. 2006. Die Sprache der Pharaonen, Großes Handwörterbuch Ägyptisch-

Deutsch. Mainz: Philipp von Zabern.

Hassan, S. 1944. Excavations at Giza V: 19331934, With Special Chapters on Methods of Excavation, the False-Door, and Other Archaeological and Religious Subjects. Cairo: Government Press.

Helck, W. 1939. Der Einfluss der Militärführer in der I 8 ägyptischen Dynastie. Leipzig: Hinrichs.

Herbin, F. R. 1994. Le Livre de Parcourir l'Éternté, Orientalia Lovaniensia Analecta 58. Leuven: Uitgeverij Peeters.

Jacquet-Gorden, H., and A. Piankoff. 1976. "The Wandering of the Soul." Bibliotheca Orientalis 33.

Kamal, A. B. 1904-1905. Stèles ptolémaiques et romaines I,' Le Caire: Imprimerie de l'Institut français d'archéologie orientale. Catalogue général des antiquités égyptiennes du Musée du Caire. Nos. $22001-22208$.

Knohl, I. 1995. The Sanctuary of Silence. Philadelphia, PA: JPS.

Leitz, C. 2002a. "Lexikon der ägyptischen Götter und Götterbezeichnungen I." In Orientalia Lovaniensia analecta IIo, edited by C. Leitz. Leuven: Peeters.

Leitz, C. 2002b. "Lexikon der ägyptischen Götter und Götterbezeichnungen III." In Orientalia Lovaniensia analecta II 2 , edited by C. Leitz. Leuven: Peeters.

Leitz, Cristian. 2002c. "Lexikon der ägyptischen Götter und Götterbezeichnungen IV." In Orientalia Lovaniensia analecta II3, edited by C. Leitz. Leuven: Peeters.

Leitz, Cristian. 2002d. "Lexikon der ägyptischen Götter und Götterbezeichnungen V." Orientalia Lovaniensia analecta II 4, edited by C. Leitz. Leuven: Peeters.

Manning, J. G. 1997. The Hauswaldt Papyri, $A$ Third Century Family Dossier from Edfu, 
Demotische studien I2. Sommerhausen: Gisela Zauzich Verlag.

Maravelia, A.-A. 2012. "Ancient Egyptian Religion \& Monotheism: A Meta-Physical and Quantum-Mechanical Approach." Journal of the Hellenic Institute of Egyptology 2: 103-5.

Maspero, G. I885. "Notes sur quelques points de grammaire et d'histoire." Zeitschrift für Agyptische Sprache und Altertumskunde 23, 3-4.

Maspero, G. 191 4. Sarcophages des époques persane et ptolémaïque I. Catalogue Général des Antiquités Égyptiennes du Musée du Caire, Nos. 2930I-29306.

Moret, A. 1902. "Le rituel du culte divin journalier en Egypte d'après les papyrus de Berlin et les textes du temple de Séti Ier à Abydos." Annales du Musée Guimet, Bibliotheque d'Etudes I 4: 144-45;

Munro, P. 1973. "Die Spätägyptischen Totenstelen." Ägptologische Forschungen 25: 252.

Murray, M. A. 1904. The Osireion at Abydos. British School of Archaeology in Egypt and Egyptian Research Account 9 (9th year). London: Bernard Quaritch.

Nagel, M. 1929. "Un papyrus funéraire de la fin du Nouvel Empire." Bulletin de l'Institut français d'archéologie orientale 29.

Naville, E. 1886. Das Ägyptische Totenbuch der XVII bis XX Dynastie. Berlin.

Petrie, W. M. F. 1909. Memphis I. London.

Piankoff, A. 1974. The Wandering of the Soul, Egyptian Religious Texts and Representations 6, Bollingen Series. Princeton, NJ: Princeton University Press.

Ranke, H. 1935. Die Ägyptischen Personennamen. Bd. I: Verzeichnis der Namen. Glückstadt: J. J. Augustin.

Redford, D. B. 2003. The Oxford Essential Guide to Egyptian Mythology. New York: Berkley Books.

Rochemonteix, M. de, and É. Chassinat 1984. Le temple d'Edfou I, Mémoires publiés par les membres de la Mission Archéologique
Française au Caire Io. Le Caire: Institut français d'archéologie orientale.

Sethe, K. 1908-1922. Die altaegyptischen Pyramidentexte' nach den Papierabdrücken und Photographien des Berliner Museums, Vols. I-4. Leipzig.

Spiegelberg, W. 1913. "Das Kolophon des liturgischen Papyrus aus der Zeit des Alexander IV." Recueil de travaux relatifs à la philologie et à l'archéologie égyptiennes et assyriennes: pour servir de bullletin à la Mission Française du Caire 35: 35-40.

Taylor, J. H., and M. Vandenbeusch, eds. 2018. Ancient Egyptian Coffins: Craft Traditions and Functionality. Leuven: Peeters.

Vischak, D. 20I 4. Community and Identity in Ancient Egypt: The Old Kingdom Cemetery at Qubbet el-Hawa. Cambridge: Cambridge University Press.

Yoyotte, J. 1969. "Bakhthis: Religion égyptienne et culture greque à Edfou." In Religions en Égypte hellénistique et romaine, edited by $\mathrm{Ph}$. Derchain, I27-4I. Paris.

Weigall, A. I910. A Guide to the Antiquities of Egypt. London.

Wild, H. 1954. "Statue de Hor Néfer au Musée des Beaux-Arts de Lausanne." Le Bulletin de l'Institut français d'archéologie orientale 54: 173-222.

Wilson, J. A. 1951. The Burden of Egypt: An Interpretation of Ancient Egyptian Culture, Oriental Institute Essay. Chicago: University of Chicago Press.

Wilson, P. 1997. A Ptolemaic Lexikon: A Lexicographical Study of the Ptolemaic Texts in the Temple of Edfu, Orientalia Lovaniensia Analecta 78. Leuven: Peeters Publishers. Wilson.

Zandee, J. 1960. Death as an Enemy: According to Ancient Egyptian Conceptions. Brill Archive. 